\title{
Subchannel Thermal-Hydraulic Modeling of an APT Tungsten Target Rod Bundle
}

by

M. A. Shadday Jr.

Westinghouse Savannah River Company

Savannah River Site

Aiken, South Carolina 29808

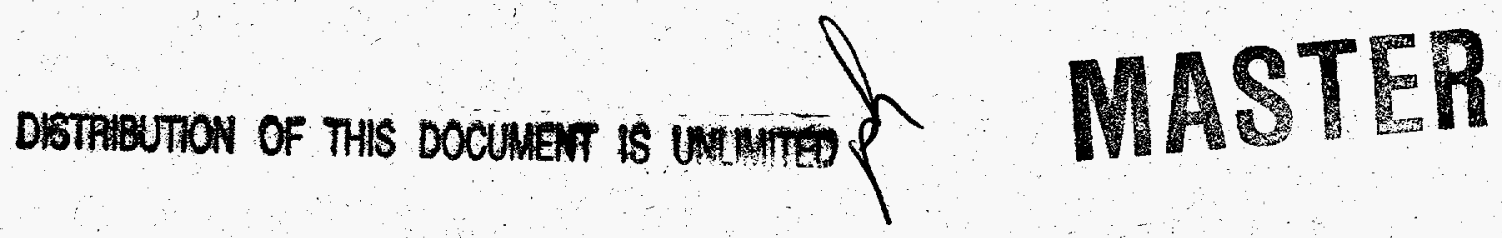

A document prepared for 1997 NATIONAL HEAT TRANSFER CONFERENCE at Baltimore, MD, USA from $8 / 10 / 97-8 / 12 / 97$.

DOE Contract No. DE-AC09-96SR18500

This paper was prepared in connection with work done under the above contract number with the U.S. Department of Energy. By acceptance of this paper, the publisher and/or recipient acknowledges the U.S. Government's right to retain a nonexclusive, royalty-free license in and to any copyright covering this paper, along with the right to reproduce and to authorize others to reproduce all or part of the copyrighted paper. 


\section{DISCLAIMER}

This report was prepared as an account of work sponsored by an agency of the United States Government. Neither the United States Government nor any agency thereof, nor any of their employees, makes any warranty, express or implied, or assumes any legal liability or responsibility for the accuracy, completeness, or usefulness of any information, apparatus, product, or process disclosed, or represents that its use would not infringe privately owned rights. Reference herein to any specific commercial product, process, or service by trade name, trademark, manufacturer, or otherwise does not necessarily constitute or imply its endorsement, recommendation, or favoring by the United States Government or any agency thereof. The views and opinions of authors expressed herein do not necessarily state or reflect those of the United States Government or any agency thereof.

This report has been reproduced directly from the best available copy.

Available to DOE and DOE contractors from the Office of Scientific and Technical Information, P.O. Box 62, Oak Ridge, TN 37831; prices available from (615) 576-8401.

Available to the public from the National Technical Information Service, U.S. Department of Commerce, 5285 Port Royal Road, Springfield, VA 22161. 


\section{DISCLAIMER}

Portions of this document may be illegible electronic image products. Images are produced from the best available original document. 


\section{SUBCHANNEL THERMAL-HYDRAULIC MODELING OF AN APT \\ TUNGSTEN TARGET ROD BUNDLE}

\author{
L. Larry Hamm \\ Westinghouse Savannah River Co. \\ Savannah River Site \\ Aiken, SC 29808 \\ (803)725-2520
}

\section{ABSTRACT}

A scoping analysis of flow through an APT target rod bundle was conducted to demonstrate that lateral crossflows are important, and therefore subchannel modeling is necessary to accurately predict thermal-hydraulic behavior under boiling conditions. A local reactor assembly code, FLOWTRAN, was modified to model axial flow along the rod bundle as flow through three concentric heated annular passages.

\section{INTRODUCTION}

The planned target for the Accelerator Production of Tritium (APT) neutron source consists of an array of tungsten rod bundles through which $\mathrm{D}_{2} \mathrm{O}$ coolant flows axially. This paper describes a preliminary modeling effort that was conducted to demonstrate the need for subchannel modeling of the target rod bundles. During normal operation, the flow through the rod bundles will be single-phase, but there is a the potential for boiling during off-normal conditions. Boiling in a rod bundle can lead to either film boiling or local dryout, both of which can result in material failure of the rod bundle. For safety analyses, models that accurately predict the onset of various boiling phenomena are necessary. The closely packed rods divide a rod bundle into a number of parallel micro-channels that communicate laterally. Since boiling is a local phenomena, a subchannel model of a rod bundle is necessary to predict its onset and progression. A driftflux version of FLOWTRAN also addresses the presence of dissolved gases and wall voidage in the highly subcooled nucleate boiling regime.

\section{GEOMETRY}

The APT target will have approximately seventeen vertical ladder-like assemblies that are aligned so the
Martin A. Shadday Jr.

Westinghouse Savannah River Co.

Savannah River Site

Aiken, SC 29808

(803)725-5060

accelerator beam passes through them sequentially. Each ladder assembly contains 15 to 28 rod bundles, each within a horizontal rung connected to two vertical manifolds. The bundles absorbing the highest power are located in the second ladder, and therefore one of these rod bundles is analyzed in this study. The rod bundles absorbing the highest power consist of 85 rods within a housing with an inside diameter of 1.416 in. $(3.597 \mathrm{~cm})$. 73 of the rods have diameters of one-eighth inch $(0.318$ $\mathrm{cm}$ ), and are arranged in a triangular lattice with a pitchto-diameter ratio of 1.15. To reduce the effects of flow channeling, twelve smaller 0.094 inch $(0.239 \mathrm{~cm})$ diameter rods are placed on the periphery of the bundle, along with six flow blockers fixed to the inside wall of the housing. The flow blockers extend the full length of the rod bundle, and therefore the flow area is constant over its length. Figure 1 shows a 1/6 pie shaped sector of the cross-section of a rod bundle, with seventeen large rods and two small rods. Also shown are two halves of the flow blockers that are fixed to the inner housing wall. The heated lengths of the rods are approximately sixteen $\mathrm{cm}$, with overall lengths of $22 \mathrm{~cm}$. Orifice plates at both ends of the rod bundle also serve as support plates for the tungsten rods.

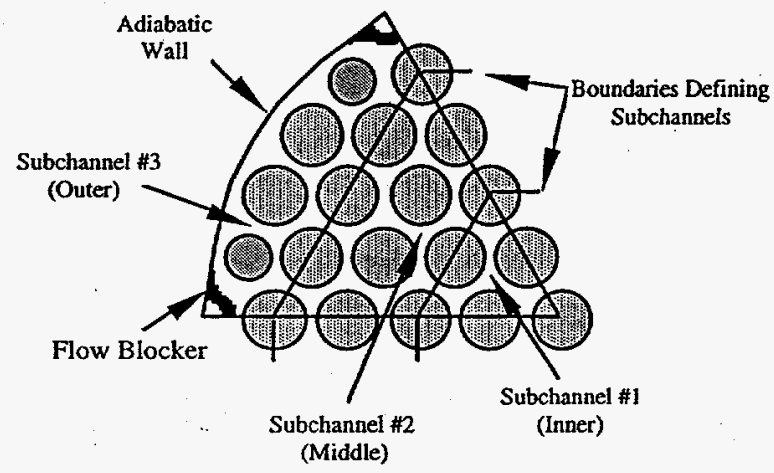

Figure 1: 1/6 sector of an APT target rod bundle. 
Under normal operating conditions, the total mass flowrate through a rod bundle in ladder No. 2 will be 1.99 $\mathrm{kg} / \mathrm{s}$, with an inlet temperature of $50^{\circ} \mathrm{C}$. The pressure in the manifold section into which the bundle flow discharges is assumed to be 152.73 psia (1.053 MPa). The nominal value for deposited power is $290 \mathrm{~kW}$, and this is assumed to be uniformly distributed among the rods and along the lengths of the rods.

\section{MODEL DESCRIPTION}

FLOWTRAN is a code that was developed at the Savannah River Site to model the flow through a single assembly in the SRS production reactors. It solves the transient conjugate heat transfer problem of coolant flow through heated concentric annular flow passages. The code is designed to handle the subcooled nucleate boiling regime. Expediency was the reason FLOWTRAN was chosen as the computational tool for this scoping study. The concentric annular flow passage geometry is fixed in FLOWTRAN, but the code was easily modified to allow radial cross-flow between the annular flow passages. Due to the preliminary nature of this study, the approximation of a rod bundle as concentric annular passages was considered reasonable.

The flow area of a rod bundle is divided into three subchannels, as shown in Fig. 1. The boundary between the inner and the middle subchannels passes through the centers of the large rods in the third ring of rods, counting radially outward from the center rod, and the boundary between the middle and outer subchannels passes through the centers of the large rods in the fifth ring of rods. The region between the central rod and the surrounding ring of six rods and also the region between the second and third rings of rods are referred to as subchannel \#1. The middle subchannel consists of the regions between the third and fifth rings of rods. The outer subchannel consists of the regions surrounding the outer ring of rods. The perimeters of the rods in rings three and five are apportioned between the two subchannels that the ring forms a boundary between, as shown in Fig. 1 .

The three subchannels are modeled as three concentric annular flow regions, separated by solid regions that represent the rods. The flow areas and the heated/wetted perimeters of the subchannels are preserved in the model. The volumes of the rods are not preserved in the annular rings. This restricts the model to steadystate conditions. The large and small rods that dump heat into the outer subchannel are represented by different annular rings, since the surface heat fluxes will be different for uniform power dissipation in the rods. Figure 2 is a schematic of the annular flow channel model. Table 1 shows the dimensions of the solid structures, and Table 2 shows the flow areas and hydraulic diameters of the three subchannels. Solid \#1, the central cylinder in the model has the same perimeter as four large rods. It represents the central rod and three of the six rods in the second ring of the rod bundle. The inner surface of solid \#2 has the same perimeter as eight large rods, three in the second ring and five in the third ring of the bundle. The outer surface of solid \#2 has the same perimeter as sixteen large rods, seven in the third ring and nine in the fourth ring of the bundle. The inner surface of solid \#3 has the same perimeter as twenty large rods, nine rods in the fourth ring and eleven rods in the fifth ring. The outer surface of solid \#3 has the same perimeter as twenty-five large rods, thirteen in the fifth ring and the twelve adjacent to the bundle housing. The inner surface of the solid \#4 has the same perimeter as the twelve small rods, and the outer surface is adiabatic. Solids \#2 and 3 are each cooled by two subchannels, and to insure that the surface heat fluxes remain the same under differing subchannel flow conditions, there are adiabatic surfaces imbedded in these solids.

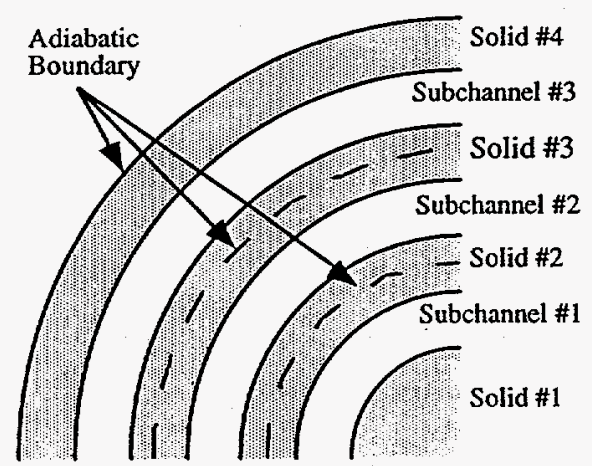

Figure 2: Schematic of the model showing the annular flow channels.

Table 1: Diameters of model solid structures.

\begin{tabular}{|c|c|c|}
\hline Solid & Inner Dia. (cm) & Outer Dia. (cm) \\
\hline$\# 1$ & 0.0 & 1.27 \\
\hline$\# 2$ & 2.54 & 5.08 \\
\hline$\# 3$ & 6.35 & 7.94 \\
\hline$\# 4$ & 2.82 & 3.56 \\
\hline
\end{tabular}

Table 2: Model subchannel flow parameters.

\begin{tabular}{|c|c|c|}
\hline Subchannel & Flow Area $\left(\mathrm{cm}^{2}\right)$ & Hyd. Dia. $(\mathrm{cm})$ \\
\hline$\# 1$ & 0.43539 & 0.1455 \\
\hline$\# 2$ & 1.3062 & 0.1455 \\
\hline$\# 3$ & 1.9594 & 0.1738 \\
\hline
\end{tabular}


Notice that the diameter of the inner surface of solid \#4, the surface that forms the outer boundary of subchannel \#3, is less than the outer diameter of solid \#3. FLOWTRAN requires that the dimensions of the solid structures be internally consistent for conduction calculations, but the flow areas are specified separately. The two solid structures that interact with a flow area do so independently through the two wetted surfaces. The frictional losses in the momentum equation are calculated with a specified hydraulic diameter.

Radial flow between the subchannels is permitted. The model allows for both pressure driven and turbulent mixing cross-flow. Turbulent mixing tends to equalize the pressures in adjacent subchannels and reduce the pressure driven cross-flow. Since the purpose of this preliminary analysis was to determine the potential impact of lateral flow on the thermal performance of the APT rod bundle, and there is considerable uncertainty in the appropriate values of turbulent mixing coefficients, turbulent mixing was turned off for the results shown in this document. Turbulent mixing will have to be addressed during future analysis efforts.

Figure 3 shows the finite-difference grid for the FLOWTRAN model. Each subchannel consists of 44 axial cells. The first and last cells are adiabatic, and the rest are heated. The test assembly has a 0.25 in. $(0.635$ $\mathrm{cm}$ ) thick orifice plate at each end of the heated section. These orifice plates also support the rods. The total flow area of each orifice plate is very close to the total flow area of the heated section. There are $35 \%$ reductions in flow areas at the points where the rods join the orifice plates, due to partial blockage of the orifice plate holes by the rod ends. The orifice plates are not modeled geometrically, but the irreversible losses are represented as form losses at the junctures of the entrance and exit regions with the heated section.

The boundary conditions for the model are the total power dissipated by the assembly, the outlet pressure, and the inlet flowrate and fluid temperature. The model predicts the axial pressure and fluid and surface temperature distributions in the three subchannels and the assembly end fittings. The drift-flux version of FLOWTRAN is capable of predicting behavior in the boiling regime up to and past the onset of significant voiding (OSV). FLOWTRAN has been successfully benchmarked against several data sets up to the point of "Ledinegg" flow instability (OFI). Table 3 is a list of the key correlations that are used in our current version of FLOWTRAN for the APT bundle analyses.

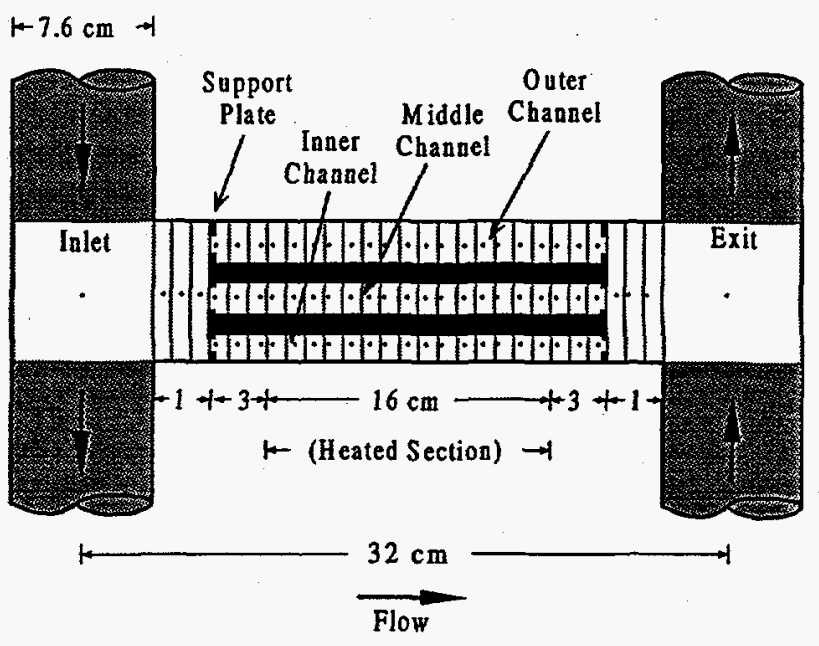

Figure 3: FLOWTRAN APT axial model schematic.

Table 3: Key correlations used in the FLOWTRAN APT model $^{1-14}$

\begin{tabular}{|c|c|c|c|}
\hline Category & Application & Originator & Comment \\
\hline \multirow[t]{4}{*}{$\begin{array}{l}\text { Frictional } \\
\text { Loss } \\
\text { Correlations }\end{array}$} & $\begin{array}{l}\text { Isothermal Axial } \\
\text { Frictional Loss }\end{array}$ & Cheng \& Todreas & $\begin{array}{l}\text { Laminar through } \\
\text { Turbulent Triangular } \\
\text { Rod Bundle }\end{array}$ \\
\hline & Heated Wall Effect & $\begin{array}{l}\text { Sieder-Tate \& } \\
\text { Dormer }\end{array}$ & Based on Flow in Tubes \\
\hline & $\begin{array}{c}\text { Bubble Roughress } \\
\text { Effect }\end{array}$ & Hancox \& Nicoll & Two-Phase Multiplier \\
\hline & $\begin{array}{c}\text { Leterial Frictional } \\
\text { Loss }\end{array}$ & Modified Lepple & $\begin{array}{l}\text { Laminar through } \\
\text { Turbulent Rod Bundles }\end{array}$ \\
\hline $\begin{array}{l}\text { Heat Transfer } \\
\text { Correlations }\end{array}$ & $\begin{array}{l}\text { SPL Fonced } \\
\text { Convection } \\
\text { FDB Regime } \\
\text { Highly SCB } \\
\text { Regime } \\
\end{array}$ & $\begin{array}{l}\text { Dituss-Boelker with } \\
\text { Markoczy } \\
\text { Adjustnem } \\
\text { Mikic \& Rohsenow } \\
\text { Bjorge \& } \\
\text { Rohsenow }\end{array}$ & $\begin{array}{l}\text { Modified Colbum for } \\
\text { Rod Bundle Geometry } \\
\text { Handles Heated Surface } \\
\text { Characteristics } \\
\text { Asymptotic Inverpolation } \\
\text { Technique }\end{array}$ \\
\hline $\begin{array}{c}\text { Wall } \\
\text { VoidrQuality } \\
\text { Comelations }\end{array}$ & $\begin{array}{l}\text { Wall Voidage in } \\
\text { Highly SCB } \\
\text { Regime } \\
\text { Wall Quality in } \\
\text { Highly SCB } \\
\text { Regime } \\
\end{array}$ & $\begin{array}{c}\text { Levy-Lee } \\
\text { Zuber \& Findlay }\end{array}$ & $\begin{array}{l}\text { Linear Wall Voidage } \\
\text { Profile } \\
\text { Dinectionallocal Drift } \\
\text { Velocity }\end{array}$ \\
\hline $\begin{array}{l}\text { Bukk } \\
\text { Void/Quality } \\
\text { Conrelations }\end{array}$ & $\begin{array}{l}\text { Bulk Voidage in } \\
\text { FDB Regime } \\
\text { Bulk Quality in } \\
\text { FDB Regime }\end{array}$ & $\begin{array}{l}\text { Kroeger \& Zuber } \\
\text { Zuber \& Findlay }\end{array}$ & $\begin{array}{l}\text { Local Quality } \\
\text { Formulation } \\
\text { Directional/Local Drift } \\
\text { Velocity }\end{array}$ \\
\hline $\begin{array}{l}\text { Onset Criteria } \\
\text { Correlations }\end{array}$ & $\begin{array}{l}\text { ONB } \\
\text { OSV } \\
\text { CHF }\end{array}$ & $\begin{array}{c}\text { Bjorge \& } \\
\text { Rohsenow } \\
\text { Saha \& Zuber } \\
\text { Bowring- Macbeth }\end{array}$ & $\begin{array}{c}\text { Maximum Cavity Size } \\
\text { Option } \\
\text { Dimensional Analysis } \\
\text { Low quality Regime. }\end{array}$ \\
\hline
\end{tabular}

Several of the correlations listed in Table 3 were selected specifically to address bundle geometries (e.g., Cheng \& Todreas frictional loss model for triangular rod bundles).

\section{RESULTS \& DISCUSSION}

Figure 4 shows the axial distributions of surface temperatures and bulk fluid temperatures for the three subchannels under normal operating conditions. The flow is single phase over the entire length of the rod 
bundle. For the outer subchannel, the surface temperatures of the large and small rods are shown separately. Notice that the inner and middle subchannels have significantly higher exit bulk temperatures than the outer subchannel. Figure 5 shows the axial distributions of surface and bulk fluid temperatures at the nominal flowrate and a bundle power of $637 \mathrm{~kW}$. This is the power at which OSV is first reached at the exit of the middle subchannel.

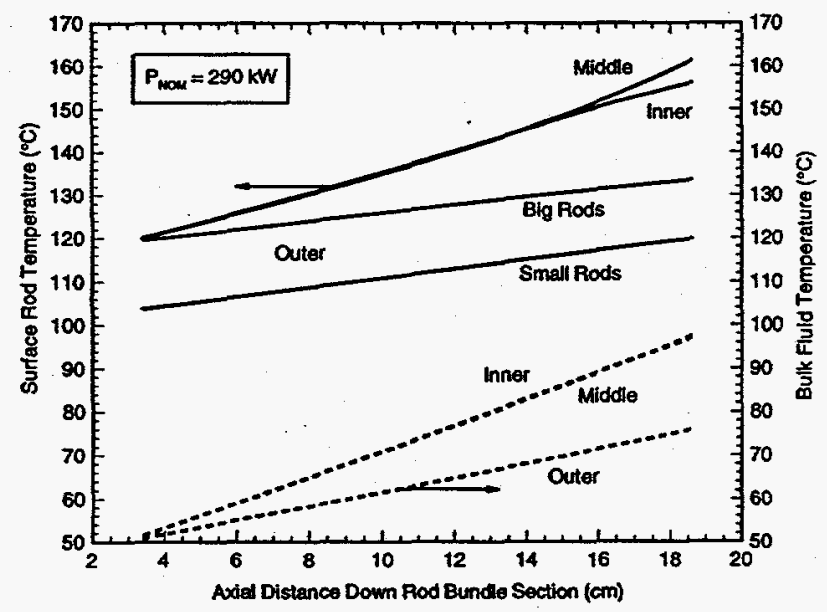

Figure 4: Axial distributions of surface temperatures and bulk fluid temperatures, (nominal power).

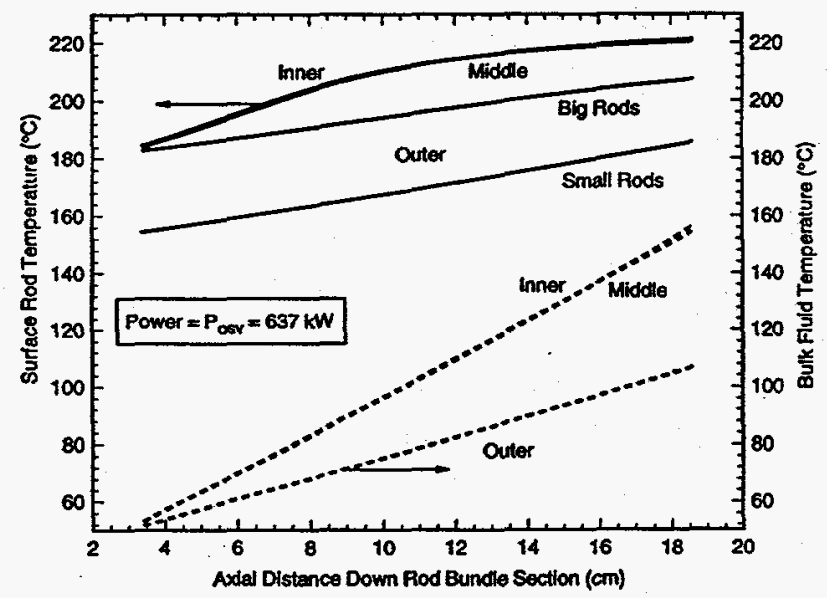

Figure 5: Axial distributions of surface temperatures and bulk fluid temperatures, (OSV power).

Figure 6 shows the axial surface heat flux distribution in the middle channel with a bundle power of $637 \mathrm{~kW}$. Along with the operating heat flux (OHF), the local onset criteria for the onset of subcooled nucleate boiling (ONB), OSV, and the critical heat flux (CHF), are shown.
As pointed out in Fig. 6, subcooled nucleate boiling is occurring over a significant portion of the inner and middle subchannels. As illustrated in Fig. 5, significant increases in the heat transfer coefficient occurs under boiling conditions resulting in reduced slopes for the surface temperatures adjacent to the inner and middle subchannels.

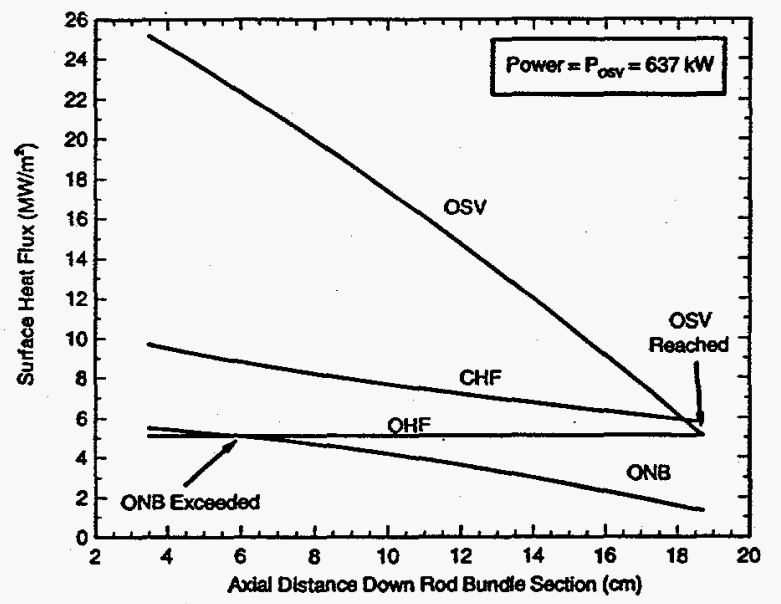

Figure 6: Axial distribution of surface heat flux and onset criteria in the middle subchannel, (OSV power).

Figure 7 shows local axial subchannel mass flowrates both with and without radial cross-flow. This is an adiabatic case at the nominal inlet flowrate and temperature. There is a significant diversion of flow from the middle-to-outer subchannels. This is due to the larger hydraulic diameter of the outer subchannel. The six flow blockers fixed to the housing wall and six small rods are intended to reduce the difference between the hydraulic diameter of the region near the housing wall and the interior of the rod bundle. The axial mass flowrate in the inner subchannel remains essentially constant because the inner and middle subchannels are hydraulically and thermally similar. Without cross-flow enabled the mass fluxes in the inner and middle subchannels are identical.

Figure 8 shows the subchannel mass flowrates for three different bundle deposited powers: $0 \quad \mathrm{~kW}$ (adiabatic), $290 \mathrm{~kW}$ (nominal), and $637 \mathrm{~kW}$ (OSV). The surfaces in contact with the inner and middle subchannels are hotter than those in contact with the outer subchannel. Increasing power tends to reduce the radially outward cross-flow due to the presence of the heated wall effect. This trend continues to grow until the power level exceeds ONB; whereby, the increasing impact of twophase pressure losses begin to negate the heated wall 
effect. Thus, at some intermediate power level there exists a minimum in radial cross-flow.

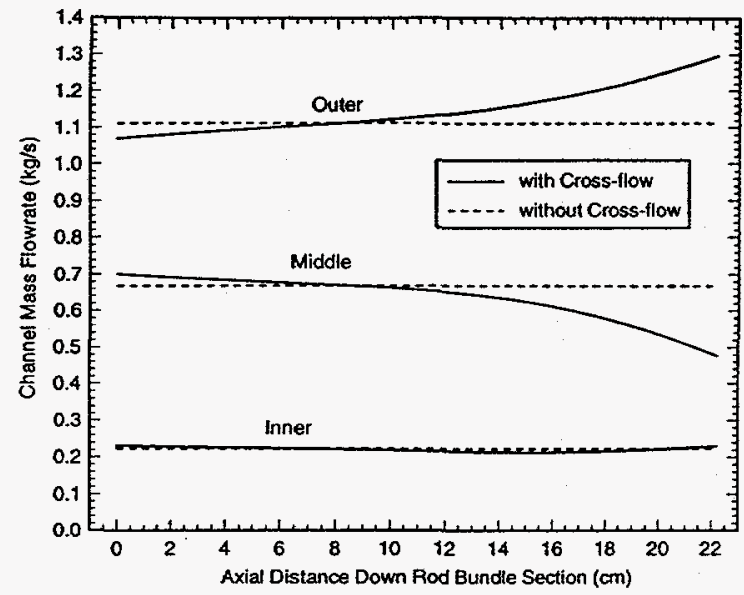

Figure 7: Subchannel mass flowrates, (zero power and nominal flowrate).

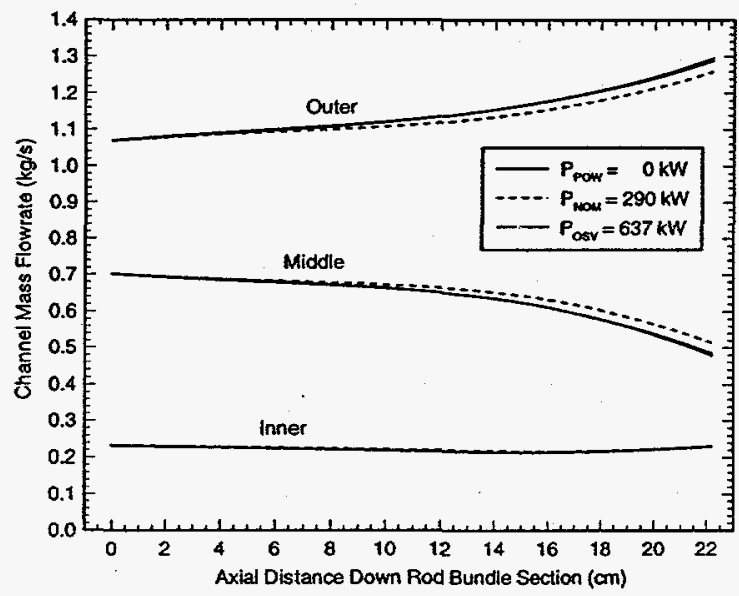

Figure 8: Subchannel mass flowrates at three powers.

Figure 9 shows the axial pressure profiles for the rod bundle through the three subchannels. The flow is adiabatic at the nominal inlet flowrate. The Bernoulli pressure drop and recovery at the entrance and exit to the rod bundle are evident, as well as the superimposed orifice plate form losses. The pressure differences between the middle and outer subchannels, that cause the diversion of flow from the middle to the outer subchannel over the downstream half of the bundle, are clearly shown. Over the last $5 \mathrm{~cm}$, the pressure in the middle subchannel is greater than in the inner subchannel, and flow is diverted out of the middle subchannel into both the inner and outer subchannels.
Figure 10 shows the axial void profiles in the three subchannels at the nominal inlet flowrate and bundle powers of 637 and $654 \mathrm{~kW} .637 \mathrm{~kW}$ is the threshold power for OSV, and $654 \mathrm{~kW}$ is the threshold power for OFI. Beyond OFI the constitutive package and governing equations within FLOWTRAN are no longer appropriate and the need to account for thermal non-equlibrium effects between phases increases. The inner and middle subchannels are in the subcooled boiling regime over most of their lengths. The void fraction remains below $3 \%$ up to OSV (i.e., wall voidage). Once this criterion is exceeded, the void fraction increases very rapidly due to bulk void contributions. The steep void fraction profile shown in Fig. 10 is typical for heated channels at low-tomoderate system pressures and narrow flow passages.

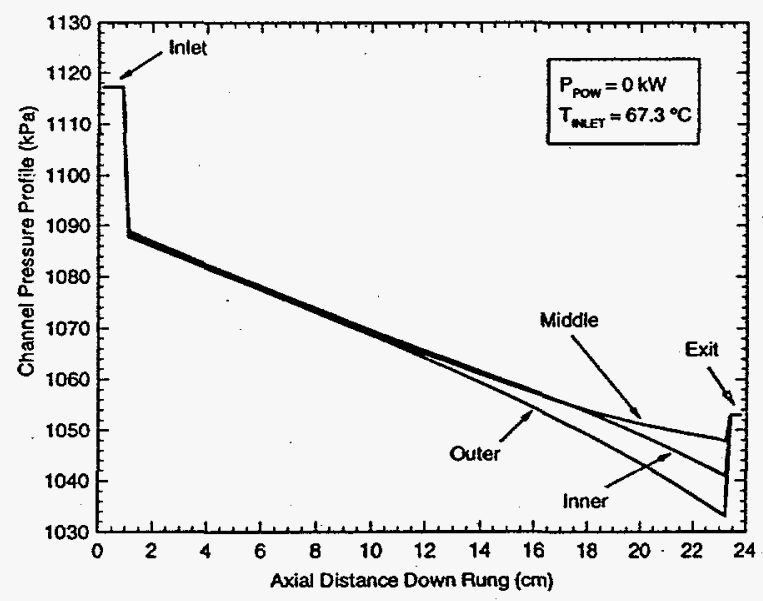

Figure 9: Axial pressure profiles, (zero power and nominal flowrate).

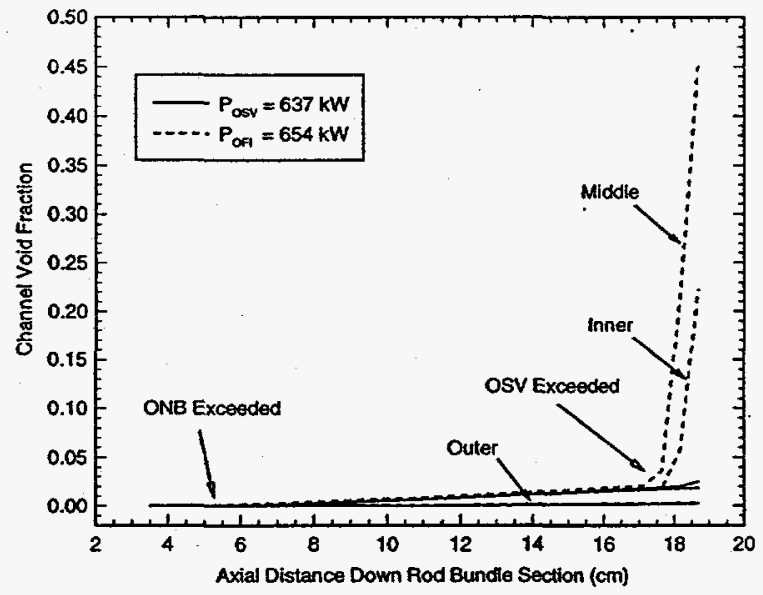

Figure 10: Axial void profiles, (at OSV and OFI powers). 
Figure 11 shows the total bundle axial pressure drop, at the nominal inlet flowrate, as a function of the bundle power. The powers for the onset of $T_{w A U}=T_{S A T}$, ONB, OSV, and OFI are also shown, along with the pressure drops along the heated lengths of the three subchannels. The reductions in pressure drop due to the heated wall effect and the decrease in bulk viscosity are evident. OSV initially occurs in the middle subchannel, and thereafter the void fraction increases rapidly, increasing diversion of flow to the other two subchannels. The increased flowrates in the inner and outer subchannels account for the sharp increases in axial pressure drops after OSV. The point labled OFI represents the minimum in the S-Shaped pressure demand curve and represents the point of "Ledinegg" flow instability for the rod bundle if the manifold supply curves are relatively flat.

Table 4 shows the bundle powers, at the nominal inlet flowrate, where several thermal onset criteria are reached. $T_{\text {wall }}$, is the point at which the wall temperature first equals the saturation temperature (i.e., zero wall superheat), and this is always the first thermal criterion that is reached. The other two boiling criteria considered are ONB and OSV. Cases with and without cross-flow are shown, and cross-flow lowers all of the power limits shown by diverting liquid flow to the cooler outer subchannel.

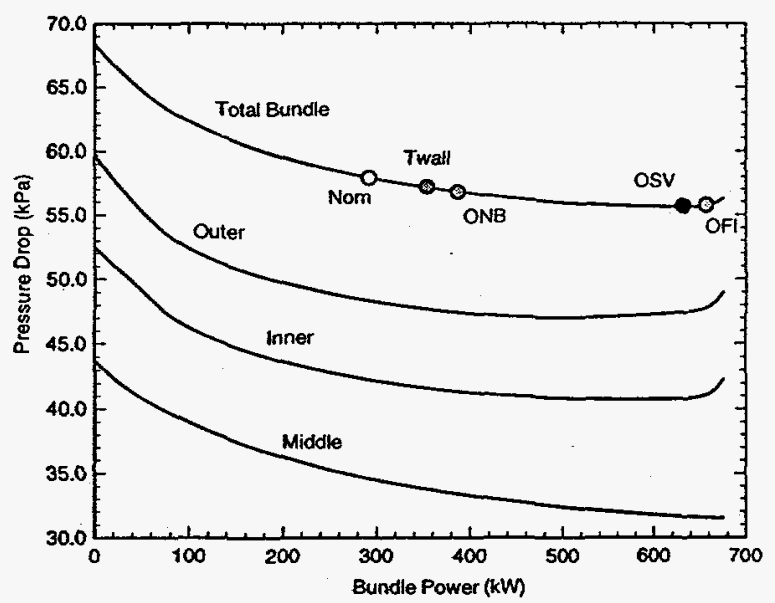

Figure 11: Axial pressure drops as functions of the bundle power.

The effect of using the Sieder-Tate ${ }^{2}$ coefficient rather than the nominal Dormer ${ }^{3}$ coefficient for the heated wall effect is shown. Both correlations apply to tube flow. The Sieder-Tate correlation is based on the Colburn analogy, and the Dormer correlation is based on flow through small diameter heated tubes. The two correlations differ in their exponent on the viscosity ratio (wall-to-bulk), 0.14 for Sieder-Tate and 0.35 for Dormer. The effect is greater with the Dormer correlation, and since it is based on small channel experiments, it is used in all of the results except for the sensitivity runs presented in Table 4 where the Sieder-Tate correlation is specified.

Table 4: Power limits about nominal conditions.

\begin{tabular}{|c|c|c|c|}
\hline $\begin{array}{c}\text { Case Run } \\
\text { About Nominal }\end{array}$ & $\begin{array}{c}\mathrm{P}_{\mathrm{TWNL}} \\
(\mathrm{kW})\end{array}$ & $\begin{array}{c}\mathrm{P}_{\mathrm{ONB}} \\
(\mathrm{kW})\end{array}$ & $\begin{array}{c}\mathrm{P}_{\mathrm{OSV}} \\
(\mathrm{kW})\end{array}$ \\
\hline $\begin{array}{c}\text { Nominal } \\
\text { Conditions }\end{array}$ & 355 & 381 & 637 \\
\hline $\begin{array}{c}\text { Sieder-Tate } \\
\text { HW Coef. }\end{array}$ & 357 & 383 & 642 \\
\hline w/o Cross-flow & 382 & 412 & 656 \\
\hline $\begin{array}{c}0.1 \times \text { Levy } \\
\text { Coef. }\end{array}$ & 355 & 381 & 639 \\
\hline $10 x$ Levy Coef. & 355 & 381 & 616 \\
\hline $\begin{array}{c}\text { Dissolved He in } \\
\text { D,O }\end{array}$ & 247 & 319 & 471 \\
\hline \multicolumn{3}{|c|}{$\left(\mathrm{P}_{\text {NOM }}=290 \mathrm{~kW} ; \mathrm{P}_{\mathrm{OFF}}=654 \mathrm{~kW}\right)$} \\
\hline
\end{tabular}

The Levy ${ }^{10}$ wall voidage model predicts the bubble diameter at the point that bubbles depart from the heated surface. The predicted void fractions prior to OSV are less than $3 \%$. The small predicted void fraction at OSV suggests that this model may be inappropriate for the small subchannels in the rod bundle. To demonstrate the sensitivity of results to this correlation, the coefficient was decreased and increased by a factor of ten. Larger amounts of wall voidage at OSV results in lower OSV powers

The effect of dissolved Helium in the $\mathrm{D}_{2} \mathrm{O}$ on the power limits is also shown in Table 4. The effect is to decrease local fluid saturation temperature and all of the power limits. The results shown apply to saturation at the system pressure of $965 \mathrm{kPa},(140 \mathrm{psia})$, and $70^{\circ} \mathrm{C}$. Based on ideal solution theory, this corresponds to an inlet liquid mole fraction of approximately $8.46 \times 10^{-5}$. These results suggest that dissolved gases are important, and they should be accounted for both in analyses and experiments. Note that the impact on OSV power results from the fact that the Saha-Zuber correlation depends dominantly on fluid subcooling. Its impact might be greatly reduced when dynamic effects associated with phase change are taken into account. 


\section{CONCLUSIONS}

It has been demonstrated that there will be a maldistribution of coolant flow within a rod bundle, even under single-phase flow conditions. This flow maldistribution leads to hotter subchannels near the axial centerline, and significant radial temperature variations. ONB occurs earlier than in the case with a uniform flow distribution. Nucleate boiling increases the local axial frictional pressure drop in a subchannel, and flow is diverted laterally out of the boiling subchannel. The local reduction in axial flow aggravates the situation. The importance of subchannel modeling of the APT target bundle, as opposed to treating the bundle as a single flow channel with uniform flow, has been demonstrated. A subchannel model that considers individual rods, such as one of the power reactor rod bundle codes, is the optimum tool for analyzing flows in the target bundles. The need for a detailed subchannel model is one of the major outcomes and purposes of this work. A modified version of THERMIT2 ${ }^{\text {ts }}$ is under consideration.

A subchannel code will be used to predict the behavior of a single APT target bundle under accident conditions. A thermal/hydraulics system code such as TRAC $^{16}$ will be used to predict overall system behavior. The two types of codes will be used in concert. The system model will provide pressure and thermal boundary conditions for a subchannel model. The detailed subchannel model will then be used in the development of a simple one dimensional target rung model for input into the overall system model.

\section{ACKNOWLEDGMENTS}

The information contained in this article was developed during the course of work under Contract No. DE-AC09-89SR18035 with the U. S. Department of Energy.

\section{REFERENCES}

1. S. K. Cheng and N. E. Todreas, "Hydrodynamic Models and Correlations for Bare and Wire-wrapped Hexagonal Rod Bundles - Bundle Friction Factors, Subchannel Friction Factors and Mixing Parameters," Nucl. Eng. and Design, 92, 227 (1986).

2. E. N. Sieder and G. E. Tate, "Heat Transfer and Pressure Drop of Liquids in Tubes," Ind. Eng. Chem., 28, 1429 (1936).

3. T. Dormer, Jr., "Pressure Drop with Surface Boiling in Small Diameter Tubes," Report No. 8767-31, Dept. of Mech. Eng., MIT, September 1964.
4. W. T. Hancox and W. B. Nicoll, "Prediction of TimeDependent Diabatic Two-Phase Water Flows," Progress in Heat and Mass Transfer, Vol. 6, 119 (1972).

5. C. E. Lapple, Fluid and Particle Mechanics, University of Delaware, 1951.

6. F. W. Dittus and L. M. K. Boelter, Univ. Calif., Berkeley, Publ. Eng., 2, 443 (1930).

7. G. Markoczy, "Konvektive Warmeubertragung in Langsangestromten Stabbundeln bei Turbulenter Stromung," Warme-und Stoffubertragung, Vol. 5, 204, 1972.

8. B. B. Mikic and W. M. Rohsenow, "A New Correlation of Pool Boiling Data Including the Effect of Heating Surface Characteristics," Trans. Am. Soc. Mech. Engrs., Series C, J. Heat Transfer, 91, 245 (1969).

9. R. W. Bjorge and W. M. Rohsenow, "Correlation of Forced Convection Boiling Heat Transfer Data," Int. J. Heat Mass Transfer, 25(6), 753 (June 1982).

10. S. Levy, "Forced Convection Subcooled Boiling Prediction of Vapour Volumetric Fraction," Int. J. Heat Mass Transfer, 10, 951 (1966).

11. N. Zuber and J. A. Findlay, "Average Volumetric Concentration in Two-Phase Flow Systems," Trans. Am. Soc. Mech. Engrs., Series C, J. Heat Transfer, 87, 453 (1965).

12. P. G. Kroeger and N. Zuber, "An Analysis of the Effects of Various Parameters on the Average Void Fractions in Subcooled Boiling," Int. J. Heat Mass Transfer, 11(2), 211 (1968).

13. P Saha and N. Zuber, "Point of Net Vapour Generation and Vapour Void Fraction in Subcooled Boiling," Proc. 5th Int. Heat Transfer Conf., Tokyo, Paper B4.7 (1974).

14. R. W. Bowring, "A Simple but Accurate Round Tube Uniform Heat Flux, Dryout Correlation Over the Pressure Range $0.7-17 \mathrm{MN} / \mathrm{m}^{2}$ (100-2500 psia)," AEEW-R 789 (1972).

15. W. H. Reed and H. B. Stewart, "THERMIT; A Computer Program for Three-Dimensional, ThermalHydraulic Analysis of Light Water Reactor Cores," MIT Report prepared for EPRI, (1978).

16. D. D. Taylor et al., "TRAC-BD1/MOD1: An Advanced Best Estimate Computer Program for Boiling Water Reactor Transient Analysis; Volume 1: Model Description," NUREG/CR-3633, EGG2294, (1984). 